TRABAJOS DE PREHISTORIA

67, N. $^{\circ}$ 2, julio-diciembre 2010, pp. 287-304, ISSN: 0082-5638

doi: $10.3989 /$ tp. 2010.10040

\title{
Metal for Zambujal: experimentally reconstructing a 5000-year-old technology
}

\section{Metal para Zambujal: reconstrucción experimental de una tecnología de 5.000 años}

\author{
Erica Hanning $(*)$ \\ Roland Gauß (**) \\ Gert Goldenberg (***)
}

\begin{abstract}
A series of 17 crucible smelting experiments were carried out as part of an interdisciplinary research project initiated to understand the innovation of copper metallurgy in the central and southern Portuguese Copper Age. The reconstructed smelting technology was based on information gathered from archaeological contexts, with emphasis on artifacts found at Zambujal and other sites in the Portuguese Estremadura, and ores collected from five different ore deposits in Portugal. Both the ore and smelting products were analysed using mineralogical and geochemical analyses, and compared with archaeological remains. Results of this comparative study are presented, and in light of technological observations made during the experiments, the role of copper production within the Chalcolithic society in southern and central Portugal is also discussed.
\end{abstract}

\section{RESUMEN}

Una serie de 17 experimentos de fundición fueron llevados a cabo como parte de un proyecto de investigación interdisciplinar, que fue iniciado con el propósito de entender las innovaciones en el ámbito de la metalurgia del cobre que se dieron en el centro y el sur de Portugal durante la Edad de Cobre. La tecnología de fundición utili-

(*) Deutsches Bergbau-Museum, Forschungsstelle Archäologie und Materialwissenschaft, Forschungsbereich Montanarchäologie, Herner Str. 45, 44787 Bochum. Correo electrónico: Erica.Hanning@bergbaumuseum.de

(**) Römisch-Germanische Kommission (Deutsches Archäologisches Institut), Palmengartenstr. 10-12 60325 Frankfurt, Germany. Correo electrónico: rgauss@rgk.dainst.de

$(* * *)$ Institut für Archäologien, Fachbereich für Ur- und Frühgeschichte sowie Mittelalter- und Neuzeitarchäologie, Universität Innsbruck, Langer Weg 11, A-6020 Innsbruck, Austria. Correo electrónico: gert.goldenberg@uibk.ac.at

Recibido: 3-V-2010; aceptado: 31-V-2010. zada en los experimentos fue recreada conforme a información recopilada y a artefactos encontrados en sitios arqueológicos, principalmente en Zambujal y otros lugares pertenecientes a la Estremadura Portuguesa. Asimismo, los minerales de cobre usados durante la fase experimental fueron recolectados en cinco yacimientos minerales de Portugal. El mineral y los productos finales del proceso de fundición fueron analizados mineralógica y geoquímicamente, para después ser comparados con el resto de las muestras arqueológicas. En el presente documento se discuten los resultados del estudio comparativo. Por último, se presenta una discusión del papel que tiene la producción de cobre en la sociedad del centro y del sur de Portugal durante el Calcolítico, basado en observaciones realizadas durante los experimentos.

Key words: Zambujal; Chalcolithic; Copper metallurgy; Crucible smelting; Experimental archaeology.

Palabras clave: Zambujal; Metallurgia de cobre; Calcolítico; Arqueología experimental; Fundición en vasija.

\section{INTRODUCTION: METAL FOR ZAMBUJAL}

Since the 1930's, ongoing excavation at the Chalcolithic fortified settlement of Zambujal (Torres Vedras), located about $50 \mathrm{~km}$ north of Lisbon and $10 \mathrm{~km}$ from the Atlantic shores, has brought to light some 900 copper artifacts, totaling roughly $3-4 \mathrm{~kg}$ of copper. Aside from circa 80 complete copper artifacts, the most numerous types of objects are small metal droplets and metal scrap. These metal objects as well as fragments of technical ceramic used for metallurgical processes are scattered around the site: in habitations as well as in the towers and other defensive structures, mixed with remains of food and other 
debris usually associated with hearths in a domestic milieu (Sangmeister 1995; Sangmeister and Schubart 1981; Müller et al. 2007; Gauß in press (1)). In the area of the central and the second fortification wall, the excavation of a house structure dating to Zambujal construction phase 3 , i.e. early Bell Beaker context (cf. Kunst and Lutz 2008), revealed the highest concentration of metallurgical debris. This could be contributed to casting, as well as smelting activity, including some $30 \mathrm{~g}$ of smelting slag and heavily vitrified crucible fragments. Other Chalcolithic sites of the Zambujal micro region revealed a similar pattern, for example, at Vila Nova de São Pedro (Azambuja) (Müller and Soares 2008).

The role metal and metallurgical processes played in the constitution and everyday life of the societies that lived in these Chalcolithic walled enclosures have been a recurring matter of debate. The traditional approach depicts metallurgy as an innovation that had a radical impact on the society, particularly in terms of knowledge transfer and resource procurement that would have been controlled by elite of particular social status (e.g. Childe 1957:282; Sahlins 1972; Sangmeister and Schubart 1981:252). In more recent models it is argued that the earliest metallurgical processes were conducted in a domestic context, by a wider group of people (e.g. Chapman 1990; Montero 1993). In 2004, a research project "Prehistoric copper metallurgy in Zambujal (Portugal): from artifact to ore deposit" was initiated to understand the innovation of copper metallurgy in the southern Portuguese Copper Age. As part of the project, it was possible to carry out a comprehensive comparative study of slag, crucible, ore and copper finds from Zambujal and other Chalcolithic sites in the Portuguese Estremadura (Müller et al. 2007; Gauß in press).

Additionally, in order to identify and date possible copper ore sources and prehistoric mining activities, extensive field surveys of over 70 different Portuguese copper occurrences took place from 2005 to 2007 (Goldenberg and Hanning in press) (Fig. 1). Besides the small occurrence from Matacães (Fig. 1, nr. 28) a few kilometers to the east of Zambujal, the closest major ore deposits

(1) Gaub in press contains a comprehensive study of the archaeometallurgical finds from Zambujal and other Portuguese Chalcolithic sites and is based on the $\mathrm{PhD}$ Thesis by Roland Gauß (formerly Müller, Müller 2008). are ca. $100 \mathrm{~km}$ distant: the mineralizations of the Ossa Morena Zone (OMZ), the Central Iberian Zone (CIZ) and the South Portuguese Zone (SPZ), which include the long-exploited ore bodies of the Southwest Iberian Pyrite Belt (IPB).

These campaigns also provided ore samples for comparative geochemical and mineralogical analyses that had led to the identification of the major copper ore/metal provider for Zambujal: According to trace element and lead isotope analyses, occurrences of the Ossa Morena Zone (Upper Alentejo and bordering Spanish Extremadura) appear to have been the most likely ore source for having provided copper for the Chalcolithic Estremadurian sites (Müller et al. 2007; Müller and Cardoso 2008; Müller and Soares 2008; Gauß in press).

Three small-scale excavations were also carried out at selected mines of the Alentejo region:

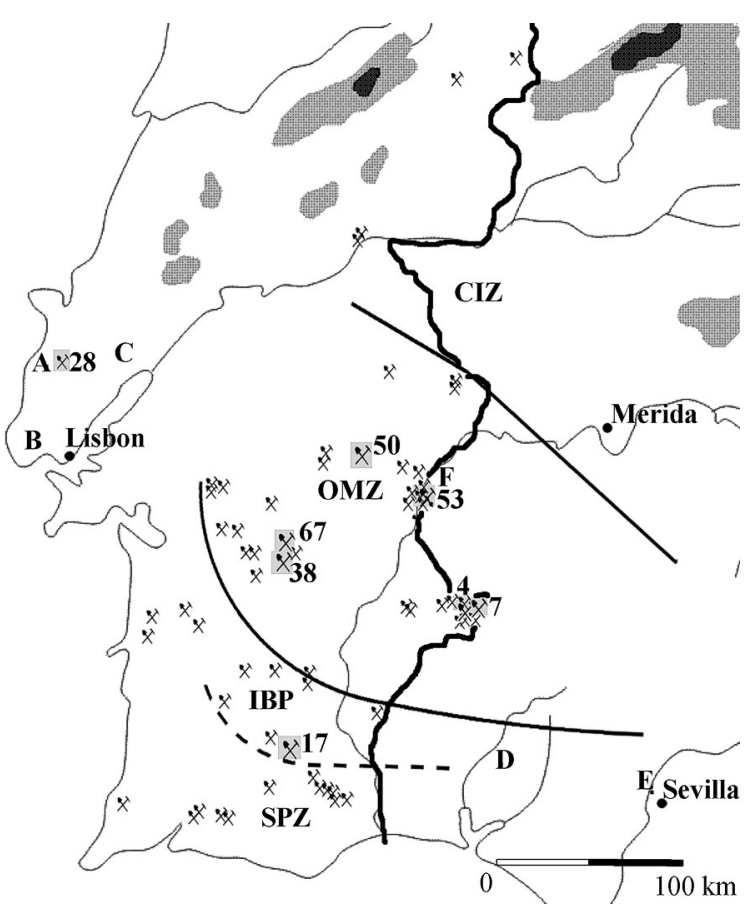

Fig. 1. Map of Southwest Iberia with sites and geological unites mentioned in the text: Copper occurences sampled during the project; sampled occurences mentioned in the text: Mercês I (4); Monte da Volta Ferreira (7); Minas de Barrigão (17); Matacães (28); Monte da Angerinha (38); Mostardeira (50); Mocissos (53). Chalcolithic settlements: Zambujal (A); Leceia (B); Vila Nova de São Pedro (C); Cabezo Juré (D); Valencina de la Concepción (E); San Blas (F). Geological Units: South Portuguese Zone (SPZ); Iberian Pyrite Belt (IPB); Ossa Morena Zone (OMZ); Central Iberian Zone (CIZ). 
Mocissos near Alandroal (Évora), Monte da Volta Ferreira near Barrancos (Beja), and Monte da Angerinha, north of Viana do Alentejo (Évora) (Fig. 1 nr. 53, 7, 38).

The mine from Monte da Volta Ferreira delivered only Roman dates. The mine from Angerinha was dominated by Roman activity, but both Bronze Age and Islamic dates recovered from the backfill of the mining trench point to both earlier and later periods of activity. Additionally at the base of the stratigraphy, two Chalcolithic radiocarbon dates could be obtained from beneath the first mining dump (Goldenberg and Hanning in press). The excavations at the mine of Mocissos were more successful in locating early signs of mining activity. According to the stratified ${ }^{14} \mathrm{C}$-dates, the multiphase mining activities could be determined from the $4^{\text {th }}$ mill. $\mathrm{BC}$ up to the Early Iron Age; modern remains $\left(19^{\text {th }}\right.$ and early $20^{\text {th }}$ century) were identified as well. In the younger prehistoric strata (Early Iron Age/Middle Bronze Age), a large quantity of stone hammers made out of quartzite pebbles from the nearby Guadiana River occur together with pottery. Excavations of the older strata, i.e. from the Early Bronze Age to Chalcolithic, brought to light two stone axes made of amphibolite and a few crucible fragments related to a copper ore smelting process (Goldenberg and Hanning in press).

\section{CRUCIBLE SMELTING: EVIDENCE AND PREVIOUS EXPERIMENTS}

Apart from a detailed and holistic archaeometallurgical study of the archaeological record, smelting experiments are indispensible for developing an appropriate understanding of the technological and organizational levels needed for producing copper in a Chalcolithic context. Smelting copper in crucibles is neither limited to a specific area, nor can be attributed to technological diffusion stemming from a single culture, nor to even to a certain epoch. The utilization of crucibles for smelting is actually a logical development: the valuable raw material (copper ore, metal) is kept under better control in a small container, so that the loss of material in the ashes of the fire is kept to a minimum; the firing process is more manageable, both in controlling the temperature, as well as controlling the reduction/oxidation (redox) atmosphere within the reactor vessel, i.e. the air flow can be concentrated into the smaller area of the crucible, greatly reducing the effort and amount of fuel needed to smelt the ore (Hauptmann 2007a: 219).

On the Iberian Peninsula, fragments of a variety of ceramic trays and bowls, whose inner surface and rims are often covered by slaggy and vitrified material, have been the key for identifying earliest smelting processes. Such fragments in Iberian contexts had already been recognized since the $19^{\text {th }}$ century as remains from copper melting ( $c f$ Siret and Siret 1888: 22, 35, 64) and then later also as smelting remains.

In in situ contexts, some sites show that the smelting areas were placed on the windy side of hills, in order to take advantage of prevailing winds, although tuyères, which indicate some sort of forced draft air supply (most likely by blowpipes), have also been found (cf Hurtado Pérez 2004; Nocete et al. 2008; Gómez Ramos 1999; Alcalde et al. 1998). The crucibles themselves were mostly discovered in association with hearths or shallow pits. In some cases they are surrounded by clay rings such as those found at Zambujal or Los Millares (Sangmeister and Schubart 1981: Pl. 31; Arribas et al. 1989; Hook et al. 1991: 66) or circular pits, sometimes with a stone base, such as at San Blas (Hunt Ortiz et al. 2009). At the remarkable sites of Cabezo Juré and Valencina de la Concepción, stone and/or clay lined metallurgical installations exist in the greatest number identified so far in an Iberian Chalcolithic context (Nocete 2004; Nocete et al. 2008). Although the archaeometallurgical remains of these sites certainly stand out in terms of production scale, they do seem to represent the continued use of a withstanding metallurgical process a crucible smelting technology (see discussion in Rovira 2006; Gauß in press).

There have been several successful attempts to smelt a variety of copper ore in crucibles ( $c f$ : Rovira and Guttierez 2003 and 2005; Rovira and Ambert 2002, Tylecote 1975: 54; Zwicker et al. 1985; Happ 1998; Miller and Bourgarit 1998; Rostoker et al. 1989; Shalev et al. 2003; Ottaway 1994: 195; Bourgarit and Mille 1997). The current experiments were based on the archaeological situation as found in south-west Iberian Chalcolithic contexts, and also used local raw materials (local ores and clay) which would have also been available to the prehistoric population (2). This is of

(2) Hanning 2008 . 
particular importance, since at the current state of research, there is no single Chalcolithic settlement in south-central Portugal where the entire chaine opératoire of primary copper production can be reconstructed (Müller et al. 2007: 21; Gauß in press). In this way, the experiments allow conclusions to be drawn whether the ores that -according to lead isotope and trace element data- come into question as possible prehistoric copper sources are smeltable in a crucible and produce remains similar to the archaeological ones. Systematic recording and analysis of the experimental components made a comparison with the artifacts, even on the microscopic and geochemical level, possible. At the same time, the experiments allowed assessment of what level of specialized training would be necessary to obtain copper from these ores, feeding back to the question of the possible necessity of a "metallurgical elite".

\section{EXPERIMENTAL CONDITIONS}

\section{Ores}

Five of the richest copper ores recovered from surface dumps of five different mining sites within Portugal were used for the experiments: Mercês I (P04c), Mostardeira (P50d), Mocissos (P53c) and Entre Aguas (P67c) from the Ossa Morena Zone; and Barrigão (P17d) from the South Portuguese Zone (Fig. 1).

The copper/copper oxide content of the ores used for the experiments was very high, i.e. varied between 20 and $60 \mathrm{wt} \%$ as indicated by the XRF analyses (Tab. 1). All ores used for the experiments exhibited extensive alteration of the sulfide mineral present in the samples, many to the point that only small relicts of the primary ore remained; such alteration is common in ores

\begin{tabular}{|c|c|c|c|c|c|c|c|c|c|c|c|}
\hline & $\begin{array}{c}\text { Mercês I } \\
\text { P04c }\end{array}$ & $\begin{array}{l}\operatorname{Exp} 15 \\
(\text { P04c) }\end{array}$ & $\begin{array}{c}\text { Barrigão } \\
\text { P17d }\end{array}$ & $\begin{array}{l}\operatorname{Exp} 8 \\
\text { (P17d) }\end{array}$ & $\begin{array}{l}\text { Mostardeira } \\
\text { P50d }\end{array}$ & $\begin{array}{c}\text { Exp 5-6 } \\
\text { (P50d) }\end{array}$ & $\begin{array}{c}\text { Mocissos } \\
\text { P53c }\end{array}$ & $\begin{array}{l}\operatorname{Exp} 4 \\
(\text { P53c) }\end{array}$ & $\begin{array}{c}\text { Entre } \\
\text { Aguas } \\
\text { P67c }\end{array}$ & $\begin{array}{l}\text { Exp 17 } \\
\text { (P67c) }\end{array}$ & $\begin{array}{c}\text { Clay } \\
\text { sample }\end{array}$ \\
\hline & Ore & Slag & Ore & Slag & Ore & Slag & Ore & Slag & Ore & Slag & Clay \\
\hline $\mathrm{Na}_{2} \mathrm{O}$ & n.d. & 1,0 & n.d. & 0,14 & n.d. & n.d. & n.d. & n.d. & n.d. & n.d. & 1,0 \\
\hline $\mathrm{MgO}$ & 0,85 & 1,7 & 5,8 & 7,8 & n.d. & 0,38 & 0,17 & 0,29 & 0,36 & 0,68 & 3,5 \\
\hline $\mathrm{Al}_{2} \mathrm{O}_{3}$ & 1,7 & 5,7 & 8,4 & 6,6 & 0,79 & 0,94 & 1,1 & 0,74 & 3,8 & 2,5 & 19 \\
\hline $\mathrm{SiO}_{2}$ & 5,9 & 22 & 28 & 36 & 4,3 & 7,6 & 42 & 64 & 40 & 59 & 56 \\
\hline $\mathrm{P}_{2} \mathrm{O}_{5}$ & 0,087 & 0,59 & 0,71 & 1,2 & 0,20 & 0,62 & 1,5 & 1,8 & 0,14 & 0,44 & 0,091 \\
\hline $\mathrm{K}_{2} \mathrm{O}$ & $\mathbf{0 , 0 3 7}$ & 1,8 & 0,92 & 1,1 & 0,073 & 0,46 & 0,20 & 0,34 & 0,59 & 1,5 & 1,4 \\
\hline $\mathrm{CaO}$ & 1,7 & 9,6 & 14 & 19 & n.d. & 2,9 & 0,066 & 0,82 & 2,0 & 6,4 & 5,4 \\
\hline $\mathrm{TiO}_{2}$ & 0,090 & 0,31 & 0,19 & 0,24 & n.d. & 0,009 & 0,028 & n.d. & n.d. & 0,10 & 0,85 \\
\hline $\mathrm{MnO}$ & 0,54 & 0,95 & 0,60 & 0,79 & 0,034 & 0,073 & 0,19 & 0,11 & n.d. & 0,078 & n.d. \\
\hline $\mathrm{Fe}_{2} \mathrm{O}_{3}$ & 18 & 40 & 8,5 & 8,1 & 51 & 62 & 9,2 & 9,6 & 3,0 & 3,7 & 12 \\
\hline $\mathrm{Cu}_{2} \mathrm{O}$ & 64 & 15 & 21 & 13 & 42 & 23 & 45 & 21 & 48 & 24 & 0,025 \\
\hline S & 6,7 & 1,3 & 4,6 & 3,3 & 0,67 & 0,40 & 0,46 & 0,41 & 1,2 & 1,4 & 0,038 \\
\hline $\mathrm{Cl}$ & n.d. & n.d. & 0,043 & 0,030 & n.d. & n.d. & 0,022 & 0,006 & $\mathbf{0 , 0 1 7}$ & n.d. & 0,021 \\
\hline As & 0,056 & n.d. & 3,6 & 0,72 & 1,2 & 0,61 & 0,047 & n.d. & 0,23 & 0,064 & n.d. \\
\hline $\mathrm{Sb}$ & n.d. & n.d. & 3,2 & 1,3 & n.d. & n.d. & n.d. & n.d. & n.d. & n.d. & n.d. \\
\hline Co & n.d. & n.d. & 0,014 & n.d. & n.d. & 0,063 & n.d. & n.d. & n.d. & n.d. & n.d. \\
\hline $\mathrm{Ni}$ & n.d. & 0,040 & $\mathbf{0 , 0 2 7}$ & 0,041 & n.d. & n.d. & 0,025 & 0,030 & 0,020 & 0,057 & 0,019 \\
\hline $\mathrm{Ag}$ & n.d. & n.d. & 0,019 & 0,016 & n.d. & n.d. & n.d. & n.d. & 0,036 & 0,015 & n.d. \\
\hline $\mathrm{Zn}$ & n.d. & n.d. & $\mathbf{0 , 3 2}$ & 0,17 & n.d. & n.d. & n.d. & n.d. & n.d. & n.d. & n.d. \\
\hline $\mathrm{Sn}$ & n.d. & n.d. & n.d. & n.d. & n.d. & n.d. & n.d. & n.d. & 0,043 & 0,025 & n.d. \\
\hline $\mathrm{Se}$ & 0,016 & 0,008 & n.d. & n.d. & n.d. & n.d. & n.d. & n.d. & n.d. & n.d. & n.d. \\
\hline $\mathrm{Sr}$ & n.d. & 0,038 & 0,016 & 0,029 & n.d. & n.d. & n.d. & 0,004 & 0,016 & 0,038 & 0,020 \\
\hline $\mathrm{Ba}$ & n.d. & 0,060 & 0,15 & 0,10 & n.d. & n.d. & n.d. & n.d. & $\mathbf{0 , 0 7 3}$ & 0,11 & 0,062 \\
\hline $\mathrm{Pb}$ & n.d. & n.d. & n.d. & n.d. & n.d. & n.d. & n.d. & n.d. & n.d. & n.d. & n.d. \\
\hline $\mathrm{Bi}$ & n.d. & n.d. & 0,066 & 0,020 & n.d. & n.d. & n.d. & n.d. & 0,29 & 0,063 & n.d. \\
\hline
\end{tabular}

Tab. 1. XRF data for the ores and the slags from 5 different experiments as well as a sample of the Portuguese clay used for the crucibles of the experiments. The data were normalized neglecting the absolute contents of carbon and hydrogen; oxygen was added stochiometrically for the major components. Some of the elements, such as iron, can be present in its divalent or trivalent form and copper, especially in the slags, can be present in both metallic and oxidic states. As the ores are mostly composed of carbonates, hydroxides and oxides, the values here represent estimates in absolute terms and therefore must be considered as "semi-quantitative". 


\begin{tabular}{|c|c|c|}
\hline Mercês I P04c & Ore & $\begin{array}{l}\text { Digenite } \mathrm{Cu}_{9} \mathrm{~S}_{5} \text {, Covellite } \mathrm{CuS} \text {, Cuprite } \mathrm{Cu}_{2} \mathrm{O} \text {, Brochantite } \mathrm{Cu}_{4} \mathrm{SO}_{4}(\mathrm{OH})_{6} \text {, Goethite } \\
\mathrm{FeO}(\mathrm{OH}) \text {, Pyrite } \mathrm{FeS}_{2} \text {, Chalcopyrite } \mathrm{CuFeS}_{2} \text {, Dolomite } \mathrm{CaMg}\left(\mathrm{CO}_{3}\right) \text {, Quartz } \mathrm{SiO}_{2}\end{array}$ \\
\hline Exp 15 sl (P04c) & Slag & $\begin{array}{l}\text { Copper } \mathrm{Cu} \text {, Cuprite, Magnetite } \mathrm{Fe}_{3} \mathrm{O}_{4} \text {, Dellafossite } \mathrm{CuFeO}_{2} \text {, Bornite } \mathrm{Cu}_{5} \mathrm{FeS}_{4} \text {, Digenite, } \\
\text { Chalcocite } \mathrm{Cu}_{2} \mathrm{~S} \text {, Magnesioferrite } \mathrm{MgFe}_{2} \mathrm{O}_{4} \text {, Monticellite } \mathrm{CaMgSiO}_{4} \text {, Quartz }\end{array}$ \\
\hline Barrigão P17d & Ore & $\begin{array}{l}\text { tite }(\mathrm{Cu}, \mathrm{Fe})_{12} \mathrm{As}_{4} \mathrm{~S}_{13} \text {, Tetrahedrite }(\mathrm{Cu}, \mathrm{Fe}, \mathrm{Zn}, \mathrm{Ag})_{12}(\mathrm{Sb}, \mathrm{As})_{4} \mathrm{~S}_{13} \text {, Chalcopyrite, } \\
\text { ite, Quartz }\end{array}$ \\
\hline $\operatorname{Exp} 8 \mathrm{~s}$ & Slag & $\begin{array}{l}\text { Magnetite, Fayalite } \mathrm{Fe}_{2} \mathrm{SiO}_{4} \text {, Chalcopyrite, Bornite, Chalcocite, Cuprite, Copper } \mathrm{Cu} \text {, Dela- } \\
\text { fossite, Akermanite (?) } \mathrm{Ca}_{2} \mathrm{MgSi}_{2} \mathrm{O}_{7} \text {, Quartz }\end{array}$ \\
\hline Most & Ore & $\begin{array}{l}\text { Delafossite, Cuprite, Brochantite, Malachite } \mathrm{Cu}_{2}(\mathrm{OH})_{2} \mathrm{CO}_{3} \text {, Hematite } \mathrm{Fe}_{2} \mathrm{O}_{3} \text {, Goethi- } \\
\text { te, Quartz }\end{array}$ \\
\hline Exp 5-6 & Slag & $\begin{array}{l}\text { Cuprite, Copper } \mathrm{Cu} \text {, Magnetite, Hematite } \mathrm{Fe}_{2} \mathrm{O}_{3} \text {, Fayalite } \mathrm{Fe}_{2} \mathrm{SiO}_{4} \text {, Iron } \mathrm{Fe} \text {, Cuprospinell? } \\
\mathrm{CuFe}_{2} \mathrm{O}_{4} \text {, Quartz }\end{array}$ \\
\hline Mocissos P53c & Ore & $\begin{array}{l}\text { Malachite } \mathrm{Cu}_{2}(\mathrm{OH})_{2} \mathrm{CO}_{3} \text {, Pseudomalachite } \mathrm{Cu}_{5}\left(\mathrm{PO}_{4}\right)_{2}(\mathrm{OH})_{4} \text {, Cuprite, Delafossite, } \\
\text { Quartz }\end{array}$ \\
\hline Exp 4 sl (P53c) & Slag & Cuprite, Copper $\mathrm{Cu}$, Delafossite, Fayalite? $(\mathrm{Fe}, \mathrm{Mn})_{2} \mathrm{SiO}_{4}$, Quartz (+ Cristobalite) \\
\hline Entre Aguas P67c & Ore & Quartz, Malachite $\mathrm{Cu}_{2}(\mathrm{OH})_{2} \mathrm{CO}_{3}$, Digenite $\mathrm{Cu}_{9} \mathrm{~S}_{5}$, Goethite \\
\hline Exp 17 sl (P67c) & Slag & Copper $\mathrm{Cu}$, Cuprite, Magnetite, Chalcocite $\mathrm{Cu}_{2} \mathrm{~S}$, Quartz (+ Cristobalite) \\
\hline
\end{tabular}

Tab. 2. XRD data listing the major phases found in the ores and the slags from 5 different experiments.

taken from the supergene and oxidation zones of an ore deposit ( $c f$. Hauptmann 2007b: 117ff). The chemical analysis and main phases present are listed in Tables 1 and 2. The ore samples were crushed to a size no greater than $5 \mathrm{~mm}$, with as much gangue material being sorted out by hand as possible. All machines and work areas were wiped down between samples to avoid contamination between ore types. For the smelting experiments, no additional fluxes were added and each smelt was carried out using one ore type only, in order to see how they would react in their "natural" states.

\section{Crucibles and Clay}

The shape of the vessels chosen for the experiments was a shallow, rectangular to semi-ovoid vessel similar to metallurgical vessels found at several sites in the Southwest of the Iberian Peninsula (cf. Nocete 2004; Hunt Ortiz 2003: 296-298; Sangmeister and Shubart 1981, pl 14). The majority of the clay used for the experimental crucibles was collected in April 2007 from a traditional clay pit at Herdade dos Baiões near Vianna do Alentejo (Alentejo, Portugal). Clay from a natural clay deposit, on the shores of Lake Constance and a third clay of industrial manufacture, which was already mixed with $50 \%$ grog, were also used. The different clays were also pre- pared separately in order to see how they reacted during the smelting process. Some of the crucibles, as well as the clay used for the tuyères were then tempered with vegetable (donkey dung) and/or mineral temper (crushed gneiss or sand).

\section{Hearths}

The handmade crucibles were placed in an open, stone ringed hearth. The design of the hearth was modified periodically during the experiments, in an effort to optimize the smelting operation. The original hearth was no more than a stone-ringed fire pit, with a $70 \mathrm{~cm}$ internal diameter, and was lightly dug in the clayey earth (Pl. I, left). However, the loss of heat into the ground and surrounding air was immense, making it difficult to maintain temperatures high enough to smelt the ore. Thus, the hearth was then gradually reduced in shape and size. The final experiments were done in a simple stone $25 \times 25 \mathrm{~cm}^{2}$ rectangular hearth where a flat stone served as the base and was surrounded on three sides by stones with a height of ca $17 \mathrm{~cm}$. The fourth side was delimitated by a shorter stone $(\mathrm{ca} .6 \mathrm{~cm}$ ) to allow easier access for the blowpipes and better air circulation (Pl. I, right). The use of a primarily stone fireplace (instead of the more common clay or clay-and-stone hearths from the Chalcolithic Portuguese contexts) was dictated in part by 
available materials and in part as a countermeasure to larger amounts of ground moisture at the experimental site.

\section{Air and Fuel Source}

The forced draft was supplied using cane/ bamboo and/or steel blowpipes tipped with clay tuyères. The air source was a combination of human lungs and a double-cylinder 2.5 litre hand pump hooked up to a single blowpipe (P1 I. left). When pumped at 20-25 cycles (one up stroke + one down stroke) per minute, the pump mimicked an intermittent blast though with a force ca. 1.25-2 times greater than a single mouth-blown blowpipe (cf. Rehder 1994: 348). The hand pump was necessary in cases where not enough volunteers were present; however a successful smelt was also conducted just using mouth-blown blowpipes, and will be discussed in more detail below.

\section{SMELTING PROCEDURE}

The hearth was preheated for an hour or more with a woodfire, to which charcoal was then added. Before each smelting experiment, a specific amount of ore was weighed out. The amount of ore used mainly depended on the capacity of the crucible - varying between 100 and 250 grams. The crucible was first slowly heated on the rocks ringing the hearth then placed into the bed of coals. A mixture of charcoal and ore was placed in the preheated crucible and then covered with more charcoal. Alternatively, the ore-filled crucible was placed in the woodfire when preheating the hearth, i.e. at lower temperatures with no forced draft, in order to bring the ore up to temperature and drive off some of the sulphur (i.e. "roast") from the samples with larger amounts of copper sulphides. Duration of the experiments varied between 30 minutes in a preheated hearth to 120 minutes, with an additional 20-76 minutes of "roasting". Periodic stirring of the crucible contents helped to assure an even and thorough reaction. A table listing the individual experiments and duration of the smelts can be seen in table 3 .

All original ores and their smelting products from 5 different experiments (one experiment for each ore type smelted) were analyzed using microscopy, microprobe analysis, X-ray diffraction,

\begin{tabular}{|c|c|c|c|c|c|c|c|}
\hline Exp & Ore type & $\begin{array}{c}\text { Ore Weight } \\
\text { grams }\end{array}$ & $\begin{array}{c}\text { Duration } \\
\text { minutes }\end{array}$ & $\begin{array}{c}\text { Nr. } \\
\text { Blowpipes: } \\
\text { Mouthblown/ } \\
\text { Handpump }\end{array}$ & $\begin{array}{c}\text { Temp. }{ }^{\circ} \mathbf{C} \text { min/max } \\
\text { Slag/waste } \\
\text { grams }\end{array}$ & $\begin{array}{c}\text { Copper } \\
\text { grams }\end{array}$ \\
\hline 1 & Entre Aguas (P67d) & 100 & 40 & $2 / 1$ & - & $* * * *$ & $* * * *$ \\
2 & Entre Aguas (P67c) & 100 & 30 & $3 / 1$ & - & 57 & 4 \\
3 & Mocissos (P53c) & 200 & 32 & $3 / 1$ & $981 / 1217$ & 126 & 14 \\
4 & Mocissos (P53c) & 250 & 35 & $4 / 1$ & $700 / 1300+$ & $>131 *$ & $>35 *$ \\
5 & Mostardeira (P50d) & 250 & 63 & $3 / 1$ & $530 / 1240$ & $* * * *$ & $* * * *$ \\
6 & Mostardeira (P50d) & $+50 * * *$ & 67 & $2 / 1$ & $865 / 1270$ & $>126 *$ & $13 *$ \\
7 & Mercês I (P04c) & 200 & 55 & $1 / 1$ & $1073 / 1310$ & 121 & 19 \\
8 & Barrigão (P17d) & 150 & 100 & $2 / 1$ & $1109 / 1340$ & $>41 *$ & $>5 *$ \\
9 & Entre Aguas (P67c) & 200 & 69 & $3 / 1$ & $760 / 1320$ & 148 & 11 \\
10 & Entre Aguas (P67c) & 200 & $57(+20 * *)$ & $3 / 1$ & $688 / 1212$ & $>66 *$ & $>11 *$ \\
11 & Mocissos (P53c) & 80 & $120(+37 * *)$ & $1 / 1$ & $433 / 1220$ & 35 & 9 \\
12 & Mostardeira (P50d) & 100 & 97 & $0 / 1$ & $530 / 1260$ & 38 & 9 \\
13 & Mercês I (P04c) & 150 & 48 & $3 / 1$ & $823 / 1300$ & $>62 *$ & $>43 *$ \\
14 & Mercês I (P04c) & 150 & $45(+59 * *)$ & $6 / 0$ & $690 / 1300$ & $>12 *$ & $>2 *$ \\
15 & Mercês I (P04c) & 150 & $43(+65 * *)$ & $3 / 1$ & $500 / 1300$ & $>21 *$ & $>34 *$ \\
16 & Entre Aguas (P67c) & 200 & $54(+45 * *)$ & $3 / 1$ & $560 / 1223$ & 122 & 5 \\
17 & Entre Aguas (P67c) & 120 & $62(+76 * *)$ & $4 / 1$ & $610 / 1278$ & 59 & 14 \\
\hline
\end{tabular}

Tab. 3. Smelting experiments carried out during the project.

$* * * *$ Smelt unsucessful, *** ore from smelt 5 combined with $50 \mathrm{~g}$ fresh ore and resmelted in smelt 6.

** additional "roasting" time where the ore-filled crucible was placed in the woodfire when preheating the hearth.

* the weights listed here do not include material taken for sectioned crucibles and slides. 
X-ray fluorescence, neutron activation analysis and lead isotope analysis (3). A clay sample from the crucible clay was also analyzed in order to be able to verify if and what type of contamination could have come from the crucibles.

\section{RESULTS}

\section{Temperature}

The temperature inside the crucible was measured using an "Omegclad-XL" nickel-chrome-nickel thermoelement, which was placed into the heart of the crucible, but above the ore to prevent slagging of the tip. The measured temperatures could only be used as a rough guide, as temperatures fluctuated rapidly depending on the distance from the tip of the tuyères, addition of new charcoal and inconsistent air flow. The use of blow pipes proved to be sufficient to melt and smelt copper: theoretically, a grown man, when breathing through a blow pipe can deliver a flow rate of 75 liters $\left(0.075 \mathrm{~m}^{3}\right)$ per minute. Thus three men blowing into a well-insulated $25 \mathrm{~cm}$ diameter furnace could sustain temperatures of about 1,200-1,250 ${ }^{\circ} \mathrm{C}$ (Rehder 1994: 348). A similar conclusion was also reached in the experiment series described here: one smelt (experiment 14), 6 blowpipes powered solely by human lungs were used, and temperatures between 1,000$1,300^{\circ} \mathrm{C}$ were easily maintained within the open crucible over a period of 45 minutes (Pl. I, right). When blowing was stopped, however, the temperature inside the crucible dropped up to $200^{\circ} \mathrm{C}$ within one minute. Due to the small opening of the tuyères (about $6 \mathrm{~mm}$ ) and limited force that human lungs can exert, the hottest zone in the fire only extended a couple of centimetres from the tip of the blowpipe, creating hotter and cooler zones within the crucible itself. Also the temperature within and below the crucible varied drastically: during experiment 7 , the thermoelement

(3) XRF (Philips 2404 with rhodium tubes) analyses of the ores: Landesamt für Geologie, Rohstoffe and Bergbau in Freiburg; XRF (Philips 2404 with rhodium tubes) of clay and smelting remains: Mineralogical-Geochemical Institute, Univeristy of Freiburg; XRD (Bruker AXSD8 Advance powder defractometer) and microprobe (SX100, vintage 1995, fitted with a $50 \mathrm{kV}$ electron gun, W-filament, five vertical WDS spectrometers, as well as an EDS Spectrometer): Mineralogical-Geochemical Institute in Freiburg. NAA and $\mathrm{Pb}$-Isotope analysis: Curt-Engelhorn-Centre for Archaeometry, Mannheim. was placed in the heart of the crucible and registered temperatures averaging $1,200^{\circ} \mathrm{C}$; but when placed underneath the crucible, the temperatures rarely reached above $500^{\circ} \mathrm{C}$. Weather conditions on the day of the smelt also affected the fuel consumption and temperature within the hearth. Although the charcoal, wood and brush were stored in a covered shelter, the charcoal and wood still absorbed some water from the atmosphere as well as from the damp ground, which naturally affected their combustion properties. It was quickly seen that on rainy days (for example Pl. I, left), it was possible to keep the fire alight but sufficient temperatures for smelting the copper ore were only reached with difficulty. Similar observations were made during smelting experiments carried out by Merkel (1990: 81): the processes were slower and sluggish on wet winter days due to damp charcoal.

\section{Crucibles}

All clays used for the experiments, with and without additional temper, were sufficient to allow the vessels to withstand smelting process. In some cases, but not in all, the slag and copper fused with the ceramic, making it necessary to break the vessels to extract the metal. When smelting ores consisting mostly of copper carbonates and oxides, however (e.g. sample P53c "Mocissos") very little or no slag was formed and the crucibles could be reused for several smelts. Many of the crucibles displayed the characteristic signs of vitrification and melting along the rims where the heat was most intense, while the bases of the vessels remained relatively cool and unaltered. Such sharp temperature gradients have also been observed in crucible fabrics from archaeological contexts, such as those from Los Millares (Hook et al. 1991: 68), Zambujal and Vila Nova São Pedro (Gauß in press). Vitrification of the clay also depended on the position of the tuyères: if the blowpipes were directed onto a wall of the crucible, instead of the center, the vessels walls tended to vitrifiy and collapse. Other times when the tips of the blowpipes were directed away from the sides, very little or no vitrification or bloating took place. Such observations should be kept in mind when evaluating possible archaeological metallurgical remains: the same metallurgical process can leave varying traces on the ce- 


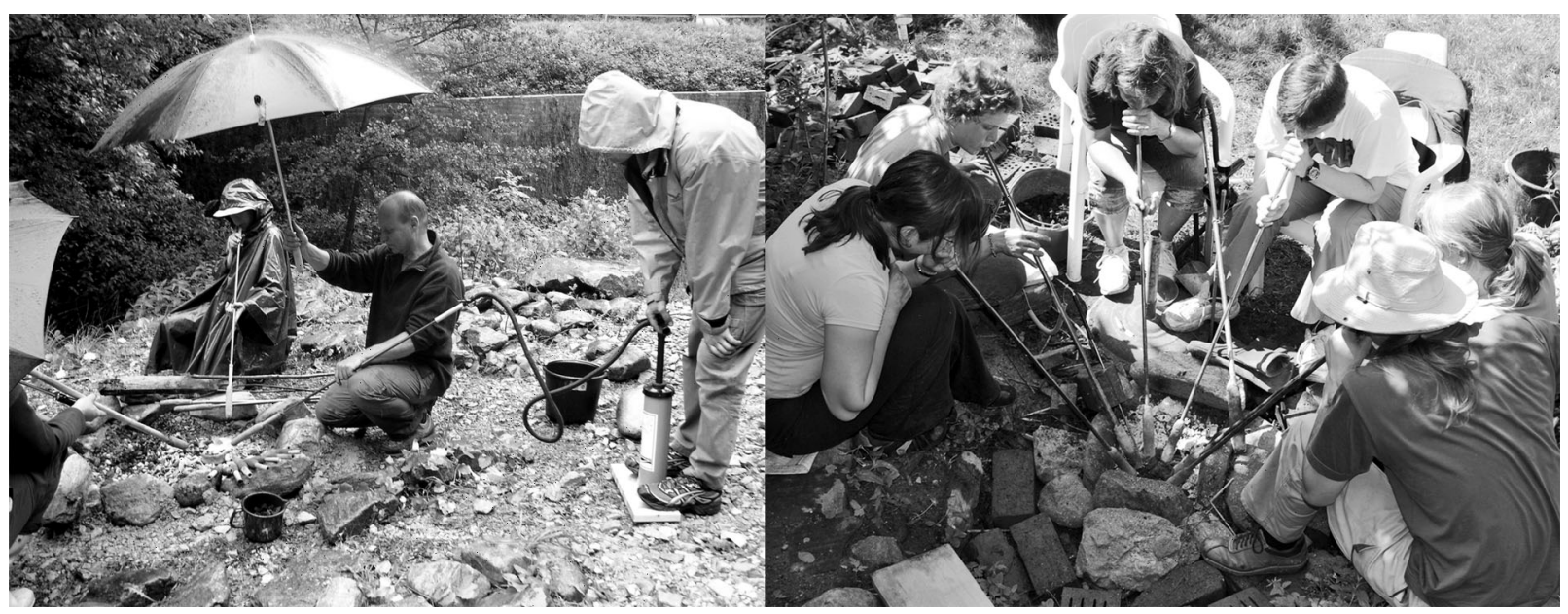

P1. I. Examples of two smelts. Left: Experiment 1. The first three experiments were carried out in a stone-ringed hearth ca. $70 \mathrm{~cm}$ in diameter. Right: Experiment 14. The last 9 experiments took place in a stone-lined hearth roughly $25 \mathrm{~cm} \times 25 \mathrm{~cm}$ in area.

ramic vessel, not only giving different results from smelt to smelt, but also leaving different traces in distinct areas of the same crucible. When the metallurgical process is unknown and only fragments of the vessel remain, as in the case of archaeological material, this can complicate the interpretation of a crucible, for example, as a primary smelting vessel or as a crucible used for refinement and/or remelting of copper.

\section{Tuyères}

Because of the heavy temper (dung and crushed gneiss), is was not necessary to pre-fire the tuyères, though when the clay was still very damp, not tempered heavily enough, or too thick, they sometimes exploded during use. The blowpipes were most efficient when placed directly on the lip of the crucible, blowing air through the charcoal (Pl. I, right). The bamboo, when not green, tended to carbonize fairly quickly underneath the clay covering, causing the tuyère to break off midlength after one or two smelts. Dipping the blowpipe periodically in water during the smelting operation, as well as using green shoots, made them last longer.

The effects of the heat from the smelting process varied widely between the tuyères. Only the tips showed signs of vitrification, the rest of the tuyère rarely showed signs of being exposed to high temperatures. The tuyères made for the experiment were extremely fragile once the under- lying bamboo had burned away, and could be easily crushed in one hand, leaving barely a trace only a few weeks after abandoning the experimental smelting site. A similar observation was made by Lorscheider: fragments of the tuyères from his copper smelting experiments were left in the open near the smelting oven, and after two weeks and several rain showers, the fragments were barely recognizable (4).

\section{BEHAVIOR OF THE INDIVIDUAL ORE TYPES}

In general, the smelting remains from all of the experiments are characterized by small copper inclusions, relicts of partially reduced ore and quartz grains, abundant iron and copper oxides, all bound together in a silica-rich matrix.

Due to the different chemical and mineralogical compositions of the ores, each reacted in a different manner when smelted under similar conditions.

Mocissos (P53c) and Mercês I (P04c) were the most successful ores smelted, with appreciable amounts of copper metal being produced in each of the smelts. The ore from Mocissos (see P53c, Tab. 2), which consisted mainly of copper oxides and carbonates, was one of the simplest

(4) Lorscheider 1998. 


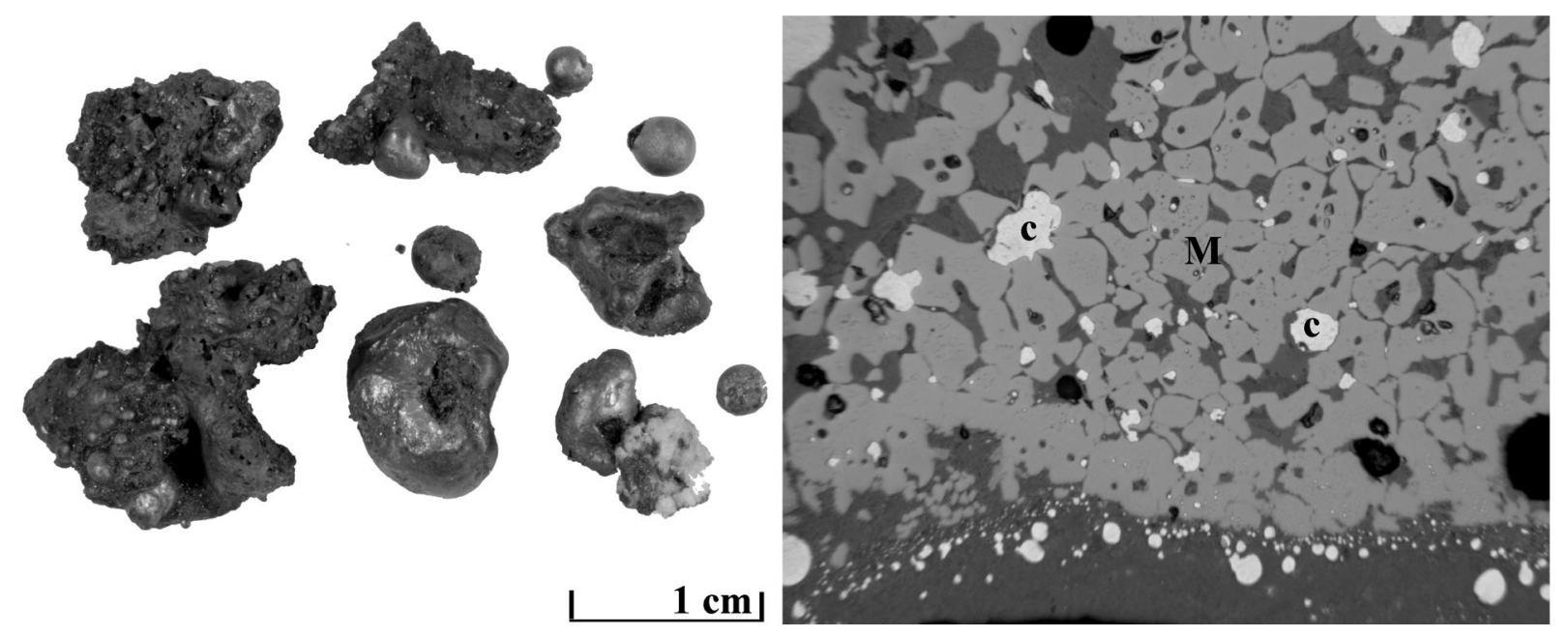

Pl. II. Left: Experiment 4 (ore: Mocissos P53c): the copper ore consisted mainly of copper oxides and carbonates and produced copper prills embedded in small amount of slaggy material. Right: photomicrograph of slag sample: Small prills of copper $(\mathrm{c})$ and magnetite $(\mathrm{m})$ embedded in a glassy matrix (reflected, plane polarized light; width $=0.35 \mathrm{~mm}$ ).

copper minerals to smelt and tended to form copper prills of up to $0.5 \mathrm{~cm}$ in diameter, with only small nodules of slaggy material (Pl. II, left). The metal exhibited in several areas an eutectic intergrowth of metallic copper and copper oxides, while other copper prills seem to be only partially consolidated, showing large cavities ringed by copper oxides. Smaller copper prills and filaments were observed trapped in the semi-molten slag (Pl. II, right), along the cracksof partially reduced ore fragments, and in the vitrified rim of the crucible.
The analysis of ore from Mercês I revealed large amounts of copper bearing minerals, but with an appreciable amount of copper sulfides as well as oxides and carbonates (Tab. 2). When smelted, this ore also produced reasonable amounts of copper, but also a layer of slag and matte (copper sulfides) (Tab. 4, exp 15). In the sectioned crucible, three distinct layers were visible to the naked eye: on top - a dark, porous slag layer mixed with the melted ceramic body and small, finely interspersed copper prills; in the middle - a silvery layer of matte; below - an ac-

\begin{tabular}{|c|c|c|c|c|c|c|c|c|c|c|c|c|c|c|}
\hline & $\begin{array}{l}\text { Exp 15 } \\
(\text { P04c) }\end{array}$ & $\begin{array}{l}\text { Exp 15 } \\
(\text { P04c) }\end{array}$ & $\begin{array}{l}\text { Exp 15 } \\
\text { (P04c) }\end{array}$ & $\begin{array}{l}\operatorname{Exp} 8 \\
(\text { P17d) }\end{array}$ & $\begin{array}{l}\operatorname{Exp} 8 \\
(\text { P17d) }\end{array}$ & $\begin{array}{r}\operatorname{Exp} 8 \\
(\text { P17d) }\end{array}$ & $\begin{array}{c}\operatorname{Exp~5-6} \\
\text { (P50d) }\end{array}$ & $\begin{array}{c}\text { Exp 5-6 } \\
\text { (P50d) }\end{array}$ & $\begin{array}{c}\text { Exp 5-6 } \\
\text { (P50d) }\end{array}$ & $\begin{array}{l}\text { Exp } 4 \\
\text { (P53c) }\end{array}$ & $\begin{array}{l}\operatorname{Exp} 4 \\
\text { (P53c) }\end{array}$ & $\begin{array}{l}\operatorname{Exp} 4 \\
(\text { P53c) }\end{array}$ & $\begin{array}{l}\text { Exp 17 } \\
(\text { P67c) }\end{array}$ & $\begin{array}{l}\text { Exp 17 } \\
\text { (P67c) }\end{array}$ \\
\hline & Metal & Metal & Matte & Speiss & Metal & Metal & Metal & Metal & Metal & Metal & Metal & Metal & Metal & Metal \\
\hline $\mathrm{Fe}$ & 0,77 & n.d. & 5,3 & n.d. & n.d. & n.d. & 1,4 & 82 & 5,6 & 0,01 & 4,3 & 0,01 & n.d. & 0,1 \\
\hline Co & n.d. & 0,01 & 0,03 & 0,02 & n.d. & n.d. & 0,02 & 0,11 & 0,03 & n.d. & n.d. & 0,02 & n.d. & n.d. \\
\hline $\mathrm{Ni}$ & 0,25 & 0,05 & 0,02 & 5,3 & 1,2 & 1,22 & 0,01 & n.d. & 0,01 & 0,07 & 0,04 & 0,06 & 0,02 & 0,01 \\
\hline $\mathrm{Cu}$ & 99 & 99 & 72 & 57 & 94 & 94 & 99 & 7,4 & 94 & 97 & 94 & 97 & 99 & 99 \\
\hline $\mathrm{Zn}$ & n.d. & 0,01 & 0,07 & n.d. & n.d. & n.d. & n.d. & n.d. & 0,04 & n.d. & n.d. & 0,00 & n.d. & n.d. \\
\hline As & 0,06 & 0,08 & 0,01 & 3,7 & 1,2 & 1,2 & 2,5 & 7,7 & 2,0 & 1,0 & 4,6 & 1 & 0,07 & 0,43 \\
\hline $\mathrm{Sb}$ & 0,01 & 0,01 & 0,00 & 36 & 2,7 & 2,7 & n.d. & 0,03 & n.d. & 0,01 & 0,01 & n.d. & n.d. & 0,01 \\
\hline $\mathrm{Pb}$ & n.d. & n.d. & 0,00 & 0,05 & n.d. & n.d. & n.d. & 0,02 & n.d. & 0,02 & n.d. & n.d. & n.d. & 0,03 \\
\hline $\mathrm{Bi}$ & 0,05 & n.d. & 0,06 & 0,03 & n.d. & n.d. & 0,06 & 0,03 & 0,03 & 0,09 & n.d. & n.d. & 0,1 & 0,05 \\
\hline $\mathrm{Ag}$ & n.d. & 0,04 & 0,00 & 0,06 & 0,01 & 0,01 & 0,01 & n.d. & n.d. & n.d. & 0,02 & 0,03 & 0,04 & 0,32 \\
\hline $\mathrm{Sn}$ & 0,05 & 0,06 & 0,00 & 0,11 & n.d. & & 0,04 & 0,01 & n.d. & 0,04 & n.d. & n.d. & 0,01 & 0,01 \\
\hline $\mathrm{Au}$ & 0,09 & & 0,01 & n.d. & 0,01 & 0,01 & n.d. & 0,04 & n.d. & 0,08 & 0,03 & 0,05 & 0,04 & n.d. \\
\hline $\mathrm{P}$ & n.d. & 0,01 & 0,00 & 0, & & & 0, & & 0,01 & n.d. & n.d. & n.d. & 0,01 & n.d. \\
\hline $\mathrm{C}$ & 0,06 & 0,02 & 22 & 0,05 & 0,01 & 0,01 & 0,01 & n.d. & 0,01 & 0,04 & 0,04 & 0,02 & n.d. & n.d. \\
\hline
\end{tabular}

Tab. 4. Selected microprobe analysis from prills and intermetallic phases. Elemental content does not sum up to $100 \%$ due to the prescence of non analysed elements and/or elements in their oxidic states. 


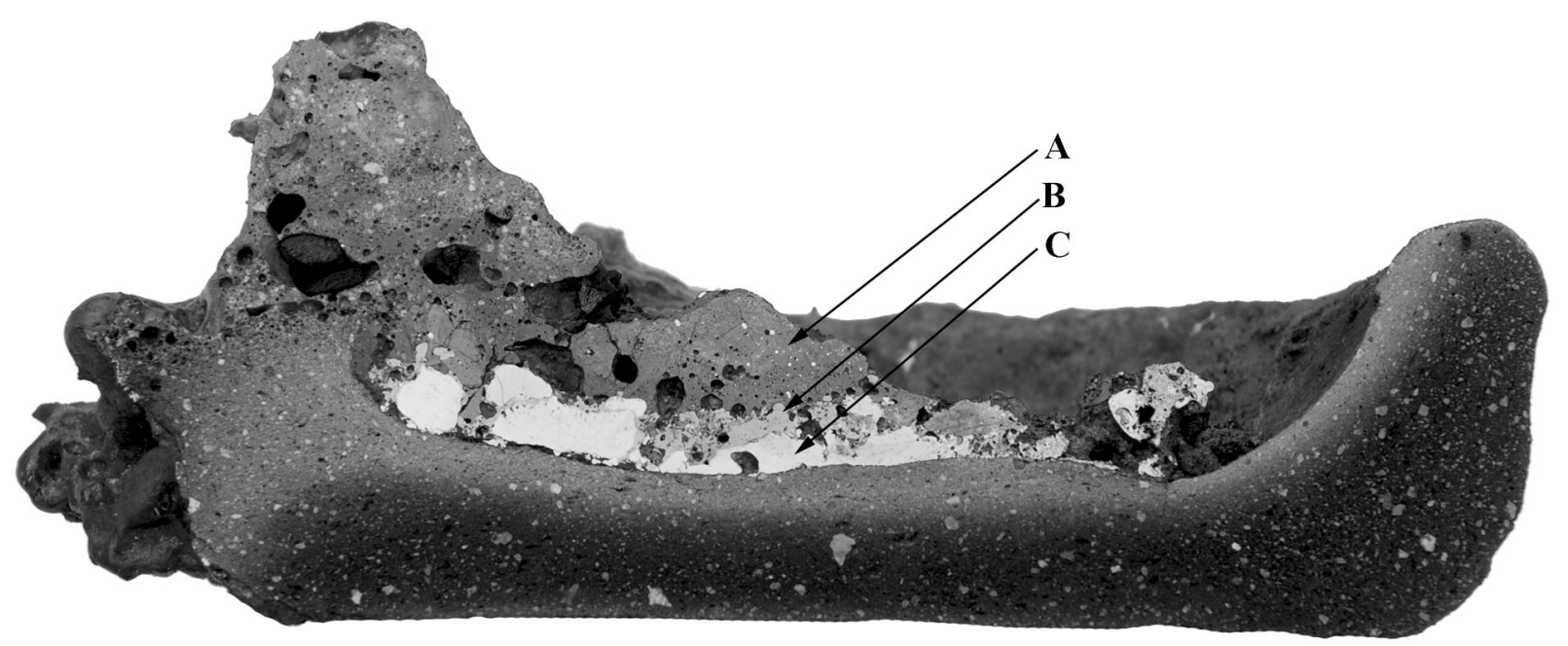

Pl. III. Experiment 14 (ore: Mercês I, P04c). In the sectioned crucible three distinct layers are visible with the naked eye: (A) a dark, porous slag layer mixed with the melted ceramic body and small, finely interspersed copper prills; (B) a silvery layer of matte (copper sulfides); (C) an accumulation of metallic copper (crucible width: $11 \mathrm{~cm}$ ).

cumulation of metallic copper (Pl. III). The copper prills contained a eutectic of copper and a copper sulfide (chalcocite $\mathrm{Cu}_{2} \mathrm{~S}$ ). Dissolution lamella within the matte of bornite $\mathrm{Cu}_{5} \mathrm{FeS}_{4}$ and chalcocite $\mathrm{Cu}_{2} \mathrm{~S}$ were also clearly identificable under the microscope.

The ore from Mostardeira (P50d) also produced copper, either as prills with a diameter of up to $1 \mathrm{~mm}$ embedded throughout the slag, or as a larger lump of metal at the bottom of the crucible, though with a very gray, dirty appearance. When examined under the microscope and electron microprobe, it became clear that the metal was not pure copper, but was instead a close interlayering of copper with significant quantities of iron (up to $5.5 \mathrm{wt} \%$ ); metallic iron with significant quantities of copper (up to $8 \mathrm{wt} \%$ ) (Tab. 4, exp 5-6); iron oxides (hematite and magnetite) and iron silicates (fayalite) (Pl. IV, left). The shape of the copper-iron/iron oxide layers are reminiscent of the botroidal structure found in the original ore, which was composed of alternating layers of copper oxides and carbonate, iron oxides and delafossite $\left(\mathrm{CuFeO}_{2}\right)(\mathrm{Pl}$. IV, right). An excess of iron in the smelt with respect to silica, as well as partial oxygen pressures that were too low at least in some places in the crucible during the smelting operation (i.e. reducing conditions that were too strong) and the physical composition of the ore itself seemed to have caused problems in removing the iron from the copper metal.

The ore from Entre Aguas (P67c) contained some $40 \mathrm{wt} \%$ of copper as indicated by the XRF analyses, but consistently produced very little metallic copper. In this case, an excess of silica and overly oxidizing atmosphere created problems when trying to smelt the ore. Although the metal was relatively pure (Tab. 4, exp 17), copper oxides had formed a eutectic inside the metal prills, as well as rimming the outside of the metal. The slag is composed almost exclusively of copper oxides (giving it a characteristic red-orange color), as well as quartz and other ore remnants, all bound in a glassy matrix (Pl. V, left). Areas near relict quartz crystals display fine symplectic intergrowths of cuprite with the glassy matrix (Pl. V, right). Very fine dendrites, too small to be accurately measured, are composed of either copper oxides or copper silicates, and many of the remaining quartz crystals had been transformed into cristobalite, the high-temperature pseudomorph of quartz, which indicates temperatures between $1,200^{\circ} \mathrm{C}$ and $1,400^{\circ} \mathrm{C}$ were reached in some parts of the crucible.

Smelting ore from Barrigão produced the least amount of metal of the five. This was the only ore to contain fahlore (see P17d, Tab. 2), and was only smelted once due to health concerns (namely the liberation of arsenic gas, which pro- 

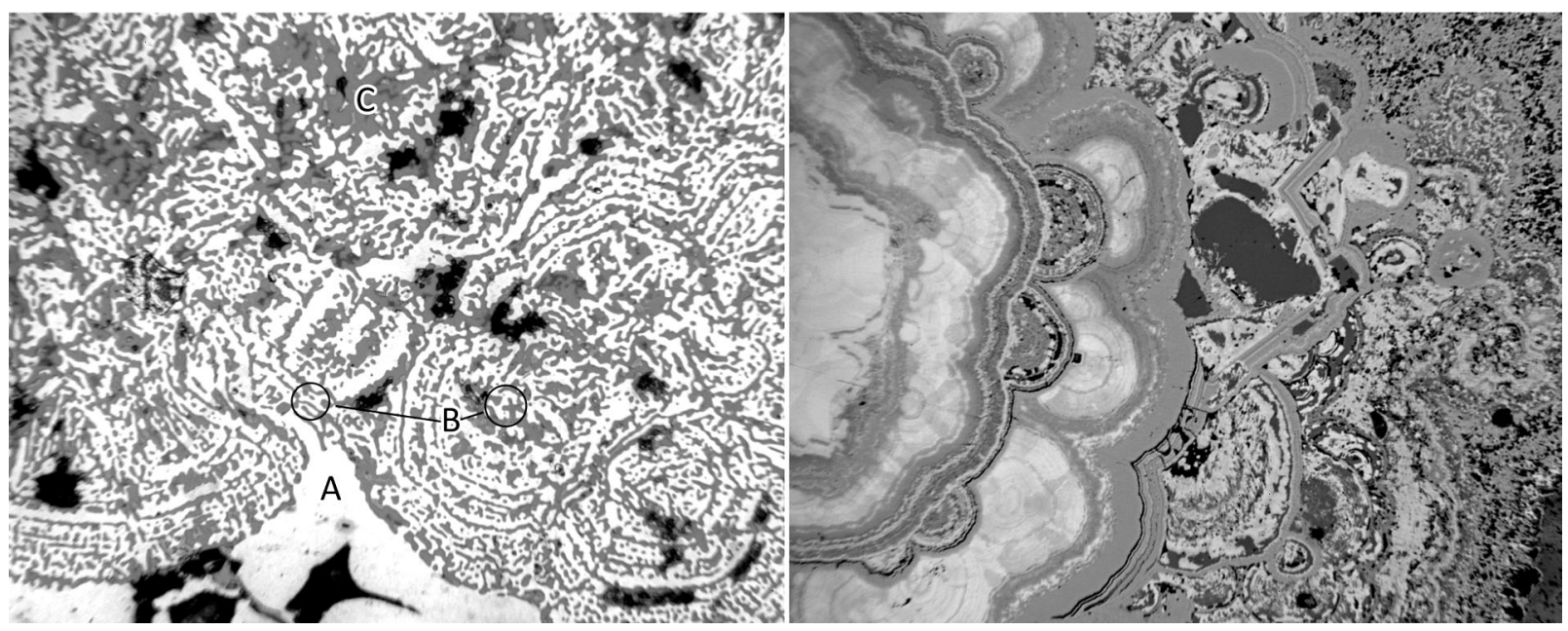

P1. IV. Experiment 5-6 (ore: Mostardeira, P50d). Left: photomicrograph of the lump of metal which collected at the bottom of the crucible. The metal was not pure copper, but was instead a close interlayering of copper with significant quantities of iron (light bands, A); metallic iron with significant quantities of copper (small whitish areas within the copper, B); and iron oxides, i.e. hematite and magnetite (medium to dark gray bands, C). Black areas are cavities (reflected, plane polarized light; width $=0.7 \mathrm{~mm}$ ). Right: photomicrograph of the ore from Mostardeira. The shape of the copper-iron-iron oxide layers from the smelt are reminiscent of the radiating botroidal formation of the ore: large bands of delafossite (very light gray, left) intergrown with smaller bands of cuprite (light gray) and goethite (medium gray) followed by fine lace-like intergrowths of $\mathrm{Cu}$ and Fe oxides and carbonates (right) (reflected, plane polarized light; width $=0.7 \mathrm{~mm}$ ).
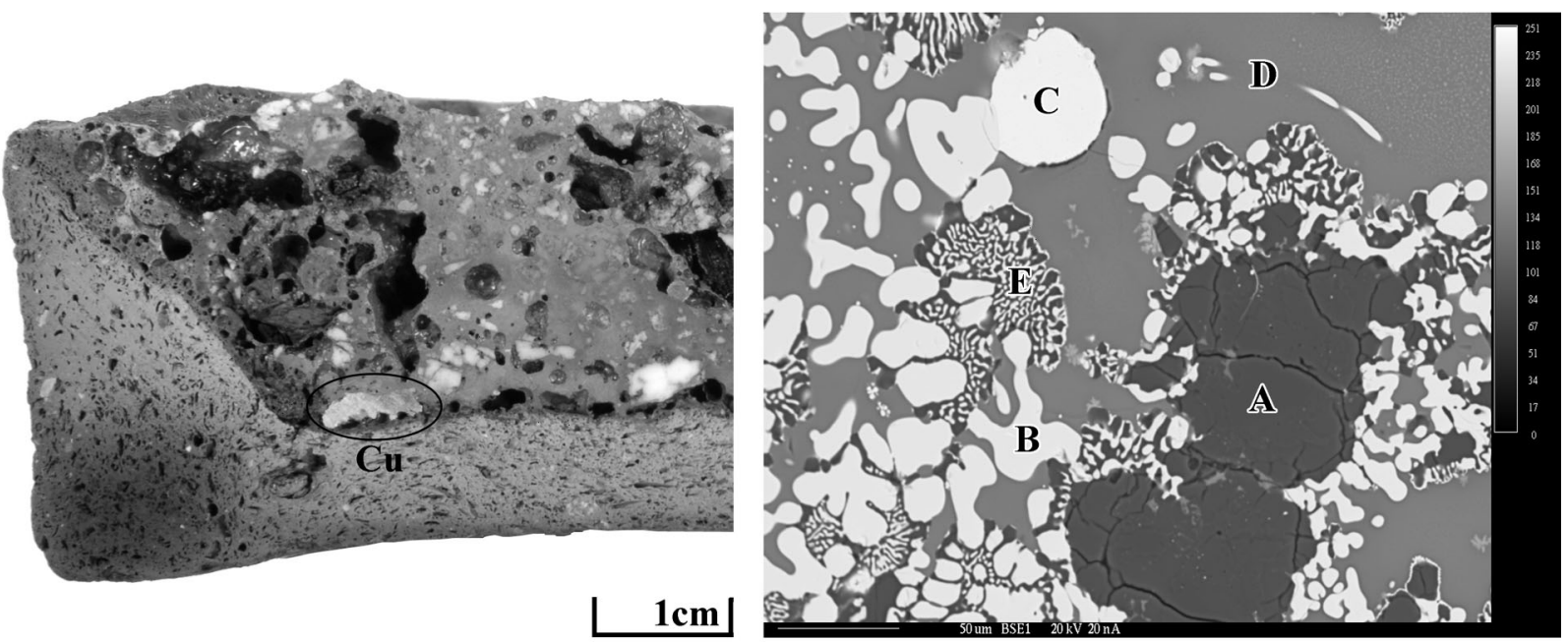

Pl. V. Experiment 17 (ore: Entre Aguas P67c). Left: section through the crucible. The slag is composed almost exclusively of quartz and other ore relicts bound in a glassy matrix with copper oxides (cuprite), giving it a characteristic red-orange color. A small copper prill $(\mathrm{Cu})$ can be seen in the bottom left hand corner of the crucible. Right: Electron microprobe image of slag from Experiment 17. A mixture of Quartz (A), copper oxides (B), and copper (C) in a glassy matrix (D). Areas near quartz crystals display fine symplectic intergrowths of cuprite and glass (E) (width ca $0.2 \mathrm{~mm}$ ).

duced a distinct garlicy smell during the experiment). As only one experiment was done using this ore, this is not sufficient to properly say if the complex sulfides present in the ore could be successfully smelted in a crucible. Only a few copper prills could be seen entrapped in the slag, several of them having a much lighter copper color - in some case almost silvery - which turned out to be speiss (intermetallic phases with large amounts of antimony and arsenic) (Tab. 4, exp 8). Copper could also be seen forming along the cracks and boundaries of partially reduced ore. 
Slag

Overall, the major components of the slags were silica, iron oxides, lime and copper oxides, in varying amounts in all cases. Microscopic inclusions of metallic copper were too small to separate mechanically from the slag, and were therefore included in the bulk analysis. Again, as no flux was intentionally added to the smelt, this leaves only ash from the wood and charcoal fuel and interaction with the clay from the crucible and tuyères as other possible flux component sources. Analysis of the unfired, non-tempered clay from the Portuguese clay pits (Herdade dos Baiões Alentejo, Portugal) revealed a composition of over $50 \% \mathrm{SiO}_{2}$, with signifficant amounts of $\mathrm{Al}_{2} \mathrm{O}_{3}, \mathrm{Fe}_{2} \mathrm{O}_{3}$ and lesser amounts of $\mathrm{CaO}, \mathrm{K}_{2} \mathrm{O}$, $\mathrm{MgO}$, and $\mathrm{Na}_{2} \mathrm{O}$ (Tab. 1). Fuel ash from wood and charcoal are mostly composed of carbon, calcium, potassium and magnesium as well as phosphorous (Etigégni and Campbell 1991: 173-175), which would account the higher levels of $\mathrm{CaO}$, $\mathrm{K}_{2} \mathrm{O}, \mathrm{MgO}$ and $\mathrm{P}_{2} \mathrm{O}_{5}$ present in the slaggy remains in comparison to the original ore. These components, along with $\mathrm{SiO}_{2}, \mathrm{MgO}, \mathrm{Fe}_{2} \mathrm{O}_{3}$ and $\mathrm{Al}_{2} \mathrm{O}_{3}$, will form the glass phase of the slag (cf. Tylecote 1987: 292).

The presence of other components in the ore, especially iron oxides and silica, can also greatly effect the smelting process. Mercês I and Mostardeira had high $\mathrm{Fe}_{2} \mathrm{O}_{3}-\mathrm{SiO}_{2}$ weight percent ratios, i.e. of 3:1 and 11:1 respectively. The other three ores were silica-rich with $\mathrm{Fe}_{2} \mathrm{O}_{3}-\mathrm{SiO}_{2}$ weight percent ratios 1:3 in the case of Barrigão; 1:4 in the case of Mocissos; and 1:13 for Entre Aguas (for values see Tab. 1).

Iron can be bound in the slag in several different phases. None of the smelting remains contained significant amounts of fayalite and so cannot be called fayalitic slags: instead they are dominated by iron oxides, especially spinel (e.g. $\left.\mathrm{Fe}_{3} \mathrm{O}_{4}, \mathrm{MgAl}_{2} \mathrm{O}_{4}, \mathrm{FeAl}_{2} \mathrm{O}_{4}\right)$, hematite $\left(\mathrm{Fe}_{2} \mathrm{O}_{3}\right)$ and delafossite $\left(\mathrm{CuFeO}_{2}\right)$.

Silica was present in the slag as either unreacted quartz grains, in the glassy matrix or as other silicate phases such as åkermanite, olivines in the solid solution fayalite-forsterite-monticellite, and various clinopyroxenes. Unreacted quartz grains are present in all samples, though the excessive amount of quartz in the ore from Entre Aguas (about $40 \mathrm{wt} \%$ silica) and poor iron oxide content (about $3 \mathrm{wt} \%$ ) created difficulties when smelting.
On the other hand, insufficient silica coupled with excess iron could also have led to problems in the smelt, as mentioned when discussing the ore from Mostardeira.

\section{Metal}

Metallic copper tended to collect at the bottom of the crucible and/or was trapped as small prills within a conglomerate of slaggy material. As mentioned above, it also occurs in oxides, i.e. cuprite $\left(\mathrm{Cu}_{2} \mathrm{O}\right)$, or delafossite. Experiments conducted with ores with an appreciable amount of sulfides especially those from Mercês I, also had copper sulfides in the smelting remains (i.e. matte). The copper from all of the experiments tended to be relatively pure with the most common impurities being arsenic and iron. In the case of Barrigão (P17d) appreciable amounts of antimony and nickel were also present. Trace elements tended to vary widely between different prills in the same smelt which, in the case of higher iron content, can reflect a more reducing atmosphere in some parts of the crucible. The experiments also showed that it is possible to create an arsenical copper from ores with very little arsenic content to begin with. Arsenic sublimates at $613^{\circ} \mathrm{C}$, but instead of completely oxidizing, a cementation occurs during smelting where gaseous As is absorbed by the copper metal. Arsenic tends to show a stronger affinity for metal and partitions into the metal instead of the slag, so that the metal can contain larger amounts of As than the original ore (cf. Hauptmann 2007: 205). From the XRF analyses, Barrigão ore (P17d) had arsenic levels of about $4 \mathrm{wt} \%$, Mostardeira (P50d) of 1 $\mathrm{wt} \%$ and Entre Aguas (P67c) of $0.2 \mathrm{wt} \%$. In the case of the ores from Mercês I (P04c) and Mocissos (P53c), arsenic contents if less than 0.1 $\mathrm{wt} \%$ were detected. However, pure copper and arsenical copper prills (up to $3 \mathrm{wt} \%$ ) were identified in one and the same slag sample produced by smelting Mocissos ore (Tab. 4, Exp 4); a similar fluctuation of arsenic values was also observed in the case of other experimentally smelted ores.

\section{COMPARISON WITH ARCHAEOLOGICAL REMAINS}

Only very few slags have been conclusively identified in Chalcolithic contexts of southern 
and central Portugal. Besides those from Zambujal, this kind of indispensable testimony for reconstructing metallurgical processes has been found at Vila Nova de São Pedro as well as at sites of the Upper Alentejo, like São Pedro (Redondo), Fonte Ferrenha (Borba/Redondo) and Perdigões (Reguengos de Monsaraz). The few samples that have been analyzed show heterogeneous microstructures, dominated by phases and phase associations like magnetite, copper + magnetite, copper + delafossite, delafossite + magnetite, copper + glass, cuprite + glass, and magnetite + glass. Only in few cases, fayalite, speiss and metallic iron have been detected (Müller et al. 2007; Müller and Soares 2008; Gauß in press). At the sites of Cabezo Juré and Valencina de la Concepción some kilograms of slag were found, yet of a similar microstructure. The polished sections of the slags published so far do not contain a significant amount of matte (cf. Sáez et al. 2003; Nocete 2004; Nocete et al. 2008).

The heterogeneous phase composition of the experimental slags resembles those of the archaeological ones. Ranging from metallic iron and fayalite to various oxides, it reflects the strong variation in redox conditions during the smelting process within the open form of a crucible. The recurring high copper oxide content very much resembles those in the slags from the archaeological record, as e.g. found at Zambujal and Vila Nova de São Pedro. Similar phase formations have also been identified in copper slags from numerous Chalcolithic and Early Bronze Age contexts from other regions (e.g. Hauptmann 2007a: 170; Rovira 2004: 15; Sáez Ramos et al. 2003: 636). The presence of decaying quartz grains and other ore relicts indicates incomplete smelting of the crucible charge. Similar observations have been made from smelting remains at Zambujal and Vila Nova de São Pedro (Müller et al. 2007; Gauß in press) as well as at Cabezo Juré (Sáez Ramos et al. 2003: 636), and Almizaraque (Müller et al. 2004: 210).

The experimental slags differed from their archaeological counterparts in a few ways. The ores used for the experiments came from the spoil heaps of modern mines, meaning that the grade of the ore was probably not as rich as the ore available to the prehistoric miners, and so produced more waste (i.e. slag). Rich ores composed mainly of copper oxides and carbonates minerals and little gangue, which would have been avail- able to the chalcolithic metallurgists, would produce metal with little or no slag formation (cf. Shalev et al. 2003).

The relatively large quantity of copper-iron sulfide matte produced by smelting the ore from Mercês I (P04c) is not common in the chalcolithic samples from the Estremadurian settlements investigated during this project or in other contemporary settlements in southern Iberia. The same holds true for the high amounts of antimony found in the slag from smelting ores containing fahlore, such as the ore from Barrigão (P17d). Although fahlore and copper sulfides are known to have been successfully smelted from an early stage in the metallurgy at other sites, for example $\mathrm{La} \mathrm{Ca}$ pitelle du Broum near Cabrières (Hérault), AlClaus (Tarn-Et-Garonnne), in the Inn Valley (Austria), Rudna Glava (Balcans) or Ross Island (Ireland) (cf: Bourgarit et al. 2003; Bourgarit and Mille 2005; Mille and Bourgarit 1998; Höppner et al. 2005; Ryndina et al. 1999; O’Brien 2004), neither large amounts of sulfides and fahlore, nor slag containing large amounts of matte have been found in Chalcolithic and Early Bronze Age sites from the southern Iberian Peninsula, making it very unlikely that such ores were intentionally smelted at that time. Copper sulfides, when found, were more likely to have been naturally associated with the copper oxides and carbonates and unintentionally added to the crucible charge (Müller et al. 2004; Rovira 2002; Rovira 2004: 12).

\section{Copper}

The copper objects from Portuguese Chalcolithic contexts clearly differ from the experimental metal in that they show lower iron contents. This can be due to larger amounts of iron in the original ore, but is more probably directly related to higher temperatures and stronger reducing conditions in some of the experimental smelts. However the artefacts do resemble the experimentally gained copper in terms of their arsenic, antimony, silver and nickel contents; i.e. they fall in the material groups "pure copper" (Mocissos, Mostardeira), "arsenical copper rich in silver and/or antimony" (Entre Aguas) and "nickel-rich copper" (Mercês I) as defined by Gauß (in press) (Fig. 2).

The enrichment of arsenic seen in the experimental ores enforces the idea that the Chalcolithic smelters did not intentionally add arsenic ores 

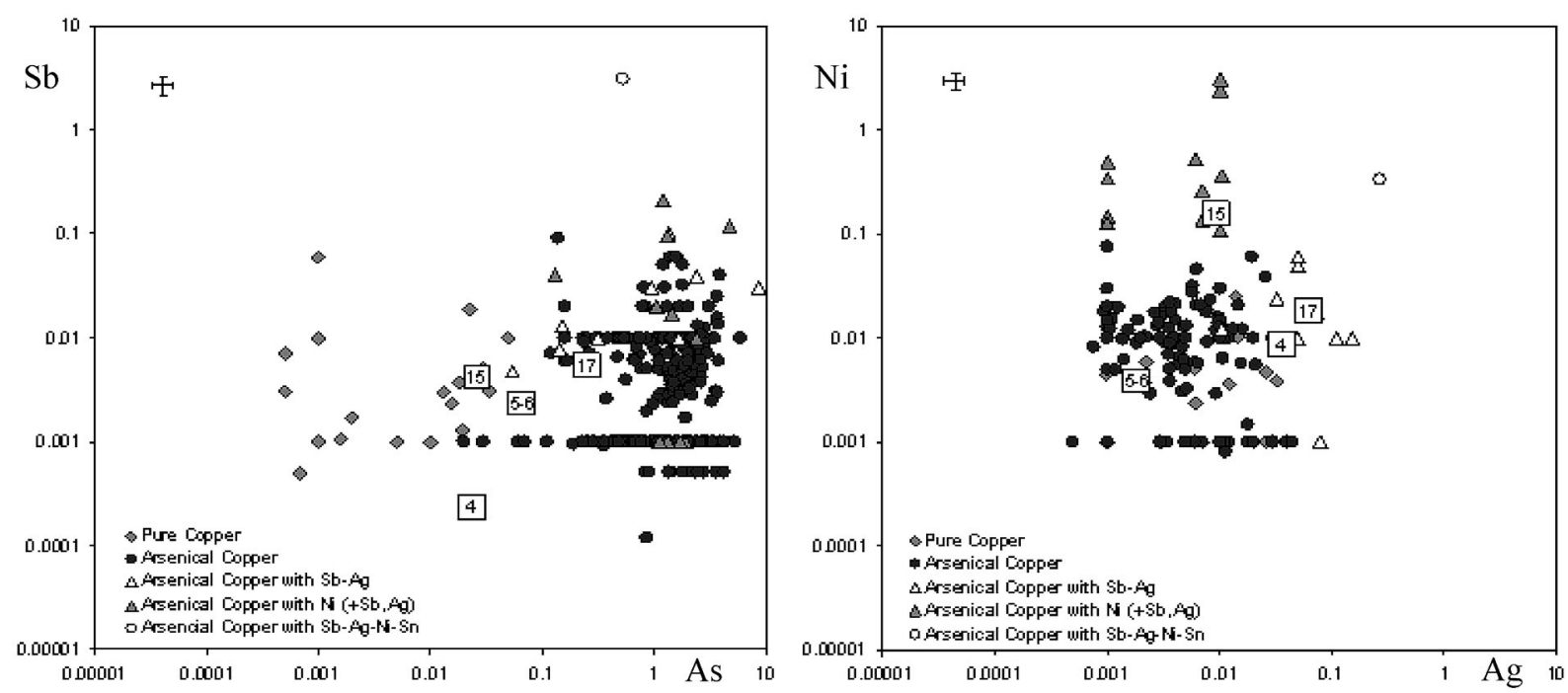

Fig. 2. Distribution patterns of As-Sb (left) and Ag-Ni (right) of the copper produced in the experiments in comparison to copper from Zambujal and other Chalcolithic settlements in Southern Portugal (based on NAA data from the experimental metal and modified diagrams after Müller and Pernicka 2009; Gauß in press). The signatures of the experiemental copper are represented by the white squares containing the number of the respective experiment.

to the smelt, but that the arsenic was a natural impurity contained within the ore. Investigations carried out on Early and Middle Bronze Age copper artifacts in Southern Portugal show that the trace element signatures of the copper and slag follow a lognormal distribution that is also present in the minor and trace element distribution of the ores, suggesting that the arsenic content was not directly controlled but originated from the smelted copper ores (Müller et al. 2007). Nonetheless, there seems to have been a deliberate choice of copper with varying arsenic contents for certain types of objects at Zambujal: elongated awls, sheet metal, Palmela points and tanged daggers tended to have higher arsenic contents than small awls and axes (Gauß in press). A possible explanation for this distinction could be a conscious association of the color of the newly smelted metal with certain mechanical properties and thus being deliberately sorted out and reserved for specific types of objects. A higher arsenic content produces a lighter colored metal as well as endowing the metal with greater hardness than pure copper (cf. Lechtmann 1996; Müller et al. 2007; Gauß in press). Another plausible hypothesis is that the higher arsenic contents of daggers and Bronze Age halberds reflects a less frequent remelting of the metal used (i.e. less use of recycled metal for these types of objects), thus limiting the loss through sublimination of the ar- senic from repetitive remelting of the metal (Rovira 2004: 19).

\section{Social organization}

The technology is based on a very simple procedure using materials available in the prehistoric landscape: at its most crude form comprising of ore in ceramic bowls placed in a domestic hearth. As long as the knowledge that certain types of stones -the distinctive green of malachite for example- produced copper when heated, then almost anyone could produce at least some copper after a little experimentation. This is possibly reflected in the scattered nature of the metallurgical remains in southern Portuguese Chalcolithic contexts, which were also many times mixed within domestic milieus. It became clear, however, during the course of the experiments that some coordination was needed in order to form a small work-group. Smelting copper ore, even in small amounts, using blowpipes proved to be difficult, if not impossible for a single person. A number of 4 to 6 people appeared to be most efficient in providing sufficient forced draft over a required period of 45 to 60 minutes. There would be enough space for this kind of group to sit around the hearth and one person in charge could easily coordinate the entire process, for example: directing 
the blowers; tending the fire and the crucible; replacing broken blowpipes; and making the decision when to stop the smelting process.

The use of bellows, or of natural draft, would alleviate the need for so many people to be present during the smelting operation; but even then, ethnographic examples have shown that smelting tends to be a group-bound activity, even when only run by two people ( $c f$. Miller 1994: 80ff; Childes and Killick 1993: 325ff; Anfinset 2000). Hence, in order to run smelting procedures, as indicated by the artifacts and as reconstructed during the experiments, part-time metal workers, who had gained adequate experiences alongside other activities, would have been sufficient. The technical abilities to produce copper in this way would not have exceeded those required for production of high quality ceramic vessels of the Portuguese Chalcolithic assemblages or for erecting and maintaining fortification walls of the $3 \mathrm{rd}$ millennium BC enclosures. However this observation is taken from a strictly technological and socioeconomic point of view. It does not take into account sociocultural factors that might have restricted access to such metallurgical knowledge, raw materials or production rights.

\section{CONCLUSION}

It was possible to successfully smelt a variety of copper ores -including oxides, carbonates and sulfides- with very simple means: clay crucibles heated with wood and charcoal, in simple stone-lined hearths, using clay-tipped blowpipes to supply the forced draft. The physical and mineralogical makeup of the smelting slags reflected the poorly reducing atmosphere within the crucibles, being characterized by small copper inclusions, relicts of partially reduced ore and quartz grains and abundant iron and copper oxides, loosely bound together in a silica-rich matrix. A considerable amount of the copper contained in the ore was never liberated as metallic copper, a sign of the limited eficiency the smelting process. These characteristics of the experimental smelting process coincide well with archaeological remains, where the open form of the vessel and hearths created difficulties in providing a reduction environment and maintaining sufficient temperature over a longer period of time. Due to their varying chemical and mineralogical compositions, each of the ores behaved quite differently when smelted under similar conditions. Especially those ores, which were primarily composed of copper carbonates and oxides, such as the ore sample from Mocissos (P53), produced slags very similar to those found at the Estremadurian Chalcolithic settlements. Other ores like Barrigão (P17) created smelting products that varied chemically from the prehistoric remains, supporting the analytical results that these ores are an unlikely source for the Zambujal copper (cf. Gauß in press).

All clay types and vessels used, with and without additional temper were able to withstand the smelting process, even if only for one smelt. It was also shown however, that the same smelting process could leave very different traces on the crucible itself, varying from almost no signs of metallurgical activity (i.e. no adherence of slag or metal, to heavily vitrified and bloated rims with multiple slag and metallic adherences. Such variability, as seen in the experimental material, must also then be kept in mind when analyzing archaeological remains, especially when no concrete evidence of primary smelting (i.e. adherences of partially reacted ore on the crucible surface) are present.

When taking into account the small-scale metallurgical remains found at Zambujal and other Portuguese Chalcolithic sites, the raw material procurement as well as the smelting operation itself could have been conducted by part-time craftsmen who reserved some of their work time on a regular basis for producing and shaping metal. In any case, the grade of craft specialisation does not seem to exceed those required for producing high-quality ceramic vessels nor from planning, erecting and maintaining complex fortification enclosure walls as known from Chalcolithic contexts in Portugal. From this perspective, the innovation of copper metallurgy does not seem to have had a decisive impact on the development of social hierarchies -at least in its initial stages.

\section{ACKNOWLEDGMENTS}

The interdisciplinary project described in the paper "Prehistoric copper metallurgy in Zambujal (Portugal): from artifact to ore deposit", was initiated by M. Bartelheim, M. Kunst, H. Parzinger 
and E. Pernicka, financed by the German Research Foundation (DFG, project no. PA 368/8) and hosted by the German Archaeological Institute (DAI) Madrid (M. Kunst), the Curt-Engelhorn Center for Archaometry Mannheim (E. Pernicka, R. Gauß), and at the Albert-Ludwigs University Freiburg (G. Goldenberg and E. Hanning). The authors would like to thank Dr. Rovira for giving them the opportunity to participate in one of his smelting experiments which took place at the Universidad Autonoma de Madrid in 2007. The knowledge gained from his expertise proved to be invaluable for the set of experiments presented in this paper. Additionally E. Hanning would like to thank Michael Kinsky of Freiburg, Germany for the donation of clay and sacrificing his garden for the sake of experimental archaeology, as well as all of the volunteers who gave a hand and manned the blowpipes during the course of the experiments.

\section{BIBLIOGRAPHY}

Alcalde, G.; Molist, M.; Montero, I.; Planagumà, L.; Saña, M. and Toledo, A. 1998: "Producciones Metalúrgicas en el Nordeste de la Península Ibérica durante el III milenio a.C.: el Taller de la Bauma del Serrat del Pont (Tortellà, Girona)". Trabajos de Prehistoria 55: 81-100.

Anfinset, N. 2000: "Mining and Smelting Copper in Contemporary Nepal. A Discussion of its Form, Function and Context". In H. Vankilde and D. Olausson (eds.): Form, Function and Context. Acta Archaeologica Lundensia 31: 203-212.

Arribas Palau, A.; Craddock, P.; Molina, P.; Rothenberg, B. and Hook, D. 1989: "Investigación arqueo-metalúrgica en yacimientos de las Edades del Cobre y del Bronce en el Sudeste de Iberia”. En C. Domergue (ed.): Coloquio internacional sobre minería y metalurgia en las antigias civilizaciones mediterráneas y europeas (Madrid 1985): 71-79. Madrid.

Bourgarit, D. and Mille, B. 1997: "La métallurgie chalcolithique de Cabrières: confrontation des données expérimentales et archéologiques en laboratoire". Archéologie en Languedoc 21: 51-63.

Bourgarit, D.; Mille, B.; Prange, M.; Ambert, P. and Hauptmann, A. 2003: "Chalcolithic Fahlore Smelting at Cabrières: Reconstruction of Smelting Processes by Archaeometallurgical Finds". Archaeometallurgy in Europe (Milano 2003) 1: 431-440. Milano.

Bourgarit, D. and Mille, B. 2005: "Nouvelles données sur l'atelier métallurgique de la Capitelle du Broum
(District Minier de Cabrières, Hérault, France): la transformation de minerais de cuivre à base de sulfures se precise". In: P. Ambert and J. Vaquer (eds.): La première métallurgie en France et dans les Pays Limitrophes. Actes du Colloque International (Carcassonne 2002). Mémoire de la Société Préhistorique Française XXXVII: 97-108.

Chapman, R. 1990: Emerging complexity: The later prehistory of south-east Spain, Iberia and the west Mediterranean. Cambridge University Press. Cambridge.

Childe, V.G. 1957: The Dawn of Civilisation. Routledge \& Kegan Paul Ltd. London.

Childes S. and Killick, D. 1993: "Indigenous African Metallurgy: Nature and Culture". Annual Review of Anthropology 22: 317-337.

Delibes de Castro, G.; Fernández-Miranda, M.; Fernández-Posse, M.; Martín, C.; Montero, I. and Rovira, S. 1991: "Almizaraque (Almería, Spain): Archaeometallurgy during the Chalcolithic in the southeast of the Iberian Penisnula". In: J.P. Mohen (ed.): Découverte du metal: 303-315. Picard. Paris.

Etiégni, L. and Campbell, A.G. 1991: "Physical Characteristics of Wood Ash". Bioresource Technology 37: 173-178.

Fasnacht, W. 1999: "Experimentelle Rekonstruktion des Gebrauchs von frühbronzezeitlichen Blasdüsen aus der Schweiz: Kupferverhüttung und Bronzeguß”. Experimentelle Archäologie 8: 237-246.

Gauß, R. in press: Zambujal und die Anfänge der Metallurgie in der Estremadura (Portugal): Technologie der Kupfergewinnung, Herkunft des Metalls und soziokulturelle Bedeutung der Innovation. Iberia Archaeologica 15,2.

Goldenberg, G.; Hanning, E. in press: "Montanarchäologische Prospektion in Portugal (Alentejo und Algarve, 2004-2007)". Iberia Archaeologica 15,1.

Gómez Ramos, P. 1999: Obtención de Metales en la Prehistoria de la Península Ibérica. BAR International Series 753. Archaeopress. Oxford.

Gonçalves, V.S. 1987: "O povoado pré-histórico da Sala N. ${ }^{\circ} 1$ (Pedrógão, Vidigueira): notas sobre a campanha" Portugalia. Nova Série 8: 7-16.

Hanning 2008: Early Copper Metallurgy on the Iberian Peninsula - an archaeometallurgical approach. Unpublished M.A. Thesis. Albert-Ludwigs-Universität, Freiburg i. Br.

Happ, J. 1998: "La découverte de la métallurgie du cuivre à travers l'expérimentation". In M. FrèreSautot (ed.): Paléométallurgie des cuivres. Actes du colloque (Bourg-en-Bresse et Beaune 1997). Monographies Instrumentum 5: 17-27. Montagnac.

Hauptmann, A. 2007a: The archaeometallurgy of copper: The evidence from Faynan, Jordan. Springer Verlag. Berlin.

Hauptmann, A. 2007b: “Alten Berg- und Hüttenleuten auf die Finger geschaut: Zur Entschlüsselung berg-

T. P., 67, N. ${ }^{\circ} 2$, julio-diciembre 2010, pp. 287-304, ISSN: 0082-5638

doi: $10.3989 /$ tp.2010.10040 
und hüttenmännischer Techniken”. In G. Wagner, Einführung in die Archäometrie. Springer. Berlin. 117-139.

Höppner, B.; Bartelheim, M.; Huijsmans, M.; Krauss, R.; Martinek, K.P.; Pernicka, E. and Schwab, R. 2005: "Prehistoric copper production in the Inn Valley (Austria), and the earliest copper in Central Europe". Archaeometry 47.2: 293-315.

Hook, D.; Freestone, I.; Meeks, N.D.; Craddock, P.T. and Moreno Onorato, A. 1991: "Early production of copper-alloys in south-east Spain". In E. Pernicka and G.A. Wagner (eds.): Archaeometry '90. Proceedings of the International Archaeometry Symposium (Heidelberg 2-6 April 1990). Birkhauser Verlag, Basel: 65-76.

Hunt Ortiz, M.; Hurtado Pérez, V.; Montero Ruiz, I.; Rovira Liorens, S. and Santos Zalduegui, J. 2009: "Chalcolithic metal production and provenance in the site of San Blas. Cheles, Badajoz, Spain". In Archaeometallurgy in Europe 2007. 2nd International Conference. Grado Aquileia. Selected Papers: 81-92.

Hurtado Pérez, V. 2004: "San Blas: The discovery of a large chalcolithic settlement by the Guadiana river". Journal of Iberian Archaeology 6: 93-116.

Kunst, M. and Lutz, N. 2008: "Zambujal (Torres Vedras, Portugal). Zur Präzision der absoluten Chronologie durch die Untersuchungen an der vierten Befestigungslinie". Madrider Mitteilungen 49: 29-63.

Lechtmann, H. 1996: "Arsenic bronze: dirty copper or chosen alloy? A view from the Americas". Journal of Field Archaeology 23: 477-514.

Leisner, V. and Schubart, H. 1966: "Die kupferzeitliche befestigung von Pedra do Ouro, Portugal". Madrider Mitteilungen 7: 9-60.

Lorscheider, F. 1998: Experimentalarchäologische Untersuchung zur Verhüttung von Fahlerzen und ihre Konsequenzen für die frühe Kupfermetallurgie. Unpublished M.A. Thesis. Albert-Ludwigs-Universität, Freiburg i. Br.

Merkel, J.F. 1990: "Experimental reconstruction of bronze age copper smelting based on archaeological evidence from Timna". In B. Rothenberg (ed.): The ancient metallurgy of copper: archaeology-experiment-theory. Institute for Archaeo-Metallurgical Studies. London: 78-120.

Mille, B. and Bourgarit, D. 1998: "Du minerai de cuivre sulfré exploité dès le Chalcolithique: les exemples de Cabrières (Hérault) et Al Claus (Tarn et Garonne)". In M.C. Frère-Sautot (ed.): Paléométallurgie des cuivres. Monographies Instrumentum 5: 27-36.

Miller, D. 1994: "Kaonde Copper Smelting: Technical Versatility and the Ethnographic Record". In S.T. Childs (ed.): Society, Culture and Technology in
Africa. Masca Research Papers in Science and Archaeology 11 (supplement): 79-85.

Montero, I. 1993: "Bronze Age metallurgy in southeast Spain". Antiquity 67: 46-57.

Müller, R. 2008: Zambujal und die Anfänge der Metallurgie in der Estremadura (Portugal): Technologie der Kupfergewinnung, Herkunft des Metalls und soziokulturelle Bedeutung der Innovation. Unpublished $\mathrm{PhD}$-Thesis. Eberhard-Karls-Universität Tübingen.

Müller, R.; Rehren, Th. and Rovira, S., 2004: “Almizaraque and the early copper metallurgy of southeast Spain: new data". Madrider Mitteilungen 45: 33-56.

Müller, R.; Rehren, Th. and Rovira, S. 2006: “The question of early copper production at Almizaraque, SE Spain". 34th International Syposium on Archaeometry (Zaragoza 2004): 209-219. Zaragoza.

Müller, R.; Goldenberg, G.; Bartelheim, M.; Kunst, M. and Pernicka, E. 2007: "Zambujal and the beginnings of metallurgy in southern Portugal". In S. La Niece, D. Hook and P. Craddock (eds.): Metals and Mines: Studies in Archaeometallurgy. Archetype Publications. Oxford: 15-26.

Müller, R. and Cardoso, J.L. 2008: "The Origin and use of copper at the Chalcolithic fortification of Leceia (Oeiras, Portugal)". Madrider Mitteilungen 49: 64-93.

Müller, R. and Soares, A.M.M. 2008: "Traces of early copper production at the Chalcolithic fortification of Vila Nova de São Pedro". Madrider Mitteilungen 49: 94-114.

Müller, R. and Pernicka, E. 2009: "Chemical analysis in archaeometallurgy: a view on the Iberian Peninsula". In T. Kienlin and B. Roberts (eds.): Metals and Societies. Studies in honour of Barbara Ottaway. Universitätsforschungen zur prähistorischen Archäologie Band 169: 296-306. Bonn.

Nocete Calvo, F. (coord.) 2004: Odiel: proyecto de investigación arqueológica para el análisis del origen de la desigualdad social en el suroeste de la península ibérica. Junta de Andalucía. Consejería de Cultura, Sevilla.

Nocete, F.; Queipo G.; Sáez, R.; Nieto, J.M.; Inácio, N.; Bayona, M.R.; Peramo, A.; Vargas, J.M.; CruzAuñón, R.; Gil-Ibarguchi, J.I. and Santos, J.F. 2008: "The smelting quarter of Valencina de la Concepción (Seville, Spain): the specialized copper industry in a political centre of the Guadalquivir Valley during the Third millennium BC (27502500 BC)". Journal of Archaeological Science 35: 717-732.

O'Brien, W. 2004: Ross Island: Mining metal and society in early Ireland. Bronze Age Studies 6. Dept. of Archaeology N.U.I Galway. 
Ottaway, B. 1994: Prähistorische Archäometallurgie. Verlag Marie Leidorf. Espelkamp.

Rehder, J. 1994: "Blowpipes versus bellow in ancient metallurgy". Journal of Field Archaeology 21.3: 345-350.

Rostoker, W.; Pigott, V. and Dvorak, J. 1989: "Direct reduction to copper metal by oxide-sulfide mineral interaction". Archeomaterials 3: 69-87.

Rovira, S. 1998: "Metalurgia campaniforme en España: Resultados de quince años de investigación arqueometalúrgica". In M. Frère-Sautot (ed.): Paléométallurgie des cuivres. Actes du colloque (Bourg-en-Bresse et Beaune 1997) Monographies Instrumentum 5: 109-117. Montagnac.

Rovira, S. 2002: "Early slags and smelting by-products of copper metallurgy in Spain". In M. Bartelheim, E. Pernicka and R. Krause (eds.): Die Anfänge der Metallurgie in der alten Welt. Archäometrie - Freiberger Forschungen zur Altertumswissenschaft 1. Leidorf Verlag, Rahden/Westfalen: 83-98.

Rovira, S. 2004: "Technologiá Metalurgica y Cambio Cultural en la Prehistoria de la Península Ibérica”. Norba Revista de Historia 17: 9-40.

Rovira, S. 2005: "Tecnología Metalúrgica Campaniforme en la Península Ibérica. Coladas, moldeado y tratamientos postfundición". In Rojo, M.A. Guerra, R. Garrido-Pena and I. García-Martínez de Lagrán (eds.): El Campaniforme en la Península Ibérica y su Contexto Europeo. Junta de Castilla y León. Valladolid. 495-521.

Rovira, S. 2006: "Metalurgia de crisol: la obtención de cobre en la prehistoria de la Península Ibérica". De Re Metallica: 37-44.

Rovira, S. and Ambert, P. 2002: "Les céramiques à réduire le minerai de cuivre: une technique métallurgique utilisée em Ibérie, son extension en France méridionale". Bulletin de la Société Préhistorique Française 99.1: 105-126.

Rovira, S. and Gutiérrez, A. 2003: “Crónica de un proceso de fundición experimental de minerales de cobre.” In J. Fernández Manzano and J. Herrán Martínez (eds.): Mineros y Fundidoers en el inicio de la edad de los Metales: El Midi francés y el Norte de la Península Ibérica. Caja España. León: 70-74.

Rovira, S. and Guttierez, A. 2005: "Utilisation expérimentale d'un four primitive pour fonder du minerai de cuivre". In P. Ambert and J. Vaquer (eds.): La Première Métallurgie en France et dans les Pays Limitrophes. Actes du colloque international (Car- cassone 2002). Société Préhistorique Française Mémoire XXXVII: 241-248.

Ryndina, N.; Indenbaum, G. and Kolosova, V. 1999: "Copper Production from Polymetallic Sulphide Ores in the Northeastern Balkan Eneolithic Culture". Journal of Archaeological Science 26: 1059-1068.

Sáez Ramos, R.; Nocete Calvo, F.; Capitán, A.; Dolores, M. and Rovira, S. 2003: "The extractive metallurgy of copper from Cabezo Juré, Huelva, Spain: Chemical and mineralogical study of slags dated to the third millennium b.c.". The Canadian Mineralogist 41.3: 627-638.

Sahlins, M. 1972: Stone Age economics. Aldine de Gruyter. New York.

Sangmeister, E. 1995: "Zambujal. Kupferfunde aus den Grabungen 1964 bis 1973”. In E. Sangmeister and M.d.L.C Jiménez Gómez (eds.): Zambujal. Kupferfunde aus den Grabungen 1964 bis 1973: Los Amuletos de las Campaños 1964 hasta 1973. Madrider Beiträge 5.3. Mainz.

Sangmeister, E. and Schubart, H. 1981: Zambujal. Die Grabungen 1964 bis 1973. Madrider Beiträge 5.1. Philipp von Zabern, Mainz.

Shalev, S.; Happ, J. and Frere-Sautot, M. 2003: "How could have the chalcolithic people from southern Israel produced their copper tool, more than six thousand years ago?" $\mathrm{Cu}+3: 5$.

Shimada, I.; Epstein, S. and Craig, A. 1982: "Batan grande: A prehistoric metallurgical center in Peru". Science 216: 954-959.

Siret, H. and Siret, L. 1888: Les Premiers Ages du Métal dans la Sud-Est de l'Espagne. Extrait de la Bévue des questiotis scientifiques. Bruxelles.

Tylecote, R. 1975: "Can copper be smelted in a crucible?". Historical Metallurgy Group Bulletin 8: 54.

Tylecote, R. 1980: "Furnaces, crucibles, and slags". In T. Wertime and J. Muhly (eds.), The coming of the age of iron. Yale University Press. London: 183-228.

Tylecote, R. 1987: The early history of metallurgy in Europe. Longman. London.

Zwicker, U.; Greiner, H.; Hofmann K.H. and Reithinger, M. 1985: "Smelting, refining, and alloying of copper and copper alloys in crucible-furnaces during prehistoric up to Roman time", in P.T. Craddock and M.J. Hughes (eds.): Furnaces and Smelting Technology in Antiquity. British Museum Occasional Paper 48: 103-116. London. 